\title{
Retraction: Evaluation of 3D surface scanners for skin documentation in forensic medicine: comparison of benchmark
} surfaces

\author{
Wolf Schweitzer*1, Martin Häusler ${ }^{1}$, Walter Bär ${ }^{1}$ and Michael Schaepman ${ }^{2}$
}

Address: ${ }^{1}$ Institut für Rechtsmedizin, Universität Zürich, Zürich, Switzerland and ${ }^{2}$ Centre for Geo-Information, Department of Environmental Sciences, Wageningen University, The Netherlands

Email: Wolf Schweitzer* - shwi@irm.unizh.ch; Martin Häusler - hama@irm.unizh.ch; Walter Bär - baer@irm.unizh.ch;

Michael Schaepman - Michael.Schaepman@wur.nl

* Corresponding author

Published: II August 2008

BMC Medical Imaging 2008, 8:15 doi:10.1 186/147|-2342-8-15

This article is available from: http://www.biomedcentral.com/I47|-2342/8//5

(c) 2008 Schweitzer et al; licensee BioMed Central Ltd.

This is an Open Access article distributed under the terms of the Creative Commons Attribution License (http://creativecommons.org/licenses/by/2.0), which permits unrestricted use, distribution, and reproduction in any medium, provided the original work is properly cited.
Received: 5 February 2008

Accepted: II August 2008
Dr. Schweitzer submitted this article [1] to BMC Medical Imaging on the assumption that he and his co-authors had permission to use the data presented within. Since this is not the case, the authors asked for the article to be removed. Dr. Schweitzer is deeply sorry for any inconvenience this may have caused to the editorial and publishing staff. An apology is also extended to the readers and manufacturers of the scanners that were tested.

\section{References}

I. Schweitzer W, Häusler M, Bär W, Schaepman M: Evaluation of 3D surface scanners for skin documentation in forensic medicine: comparison of benchmark surfaces. BMC Medical Imaging 2007, 7:1.

\section{Pre-publication history}

The pre-publication history for this paper can be accessed here:

http://www.biomedcentral.com/1471-2342/8/15/prepub 